\title{
PENERAPAN INTERNET FINANCIAL REPORTING (IFR) PADA BANK UMUM SYARIAH DI INDONESIA
}

\author{
Ria Nur Rizqiah dan Ahmad Tarmizi Lubis \\ Program Studi Akuntansi Syariah \\ Sekolah Tinggi Ekonomi Islam SEBI \\ Email: riarizqiah@gmail.com
}

\begin{abstract}
Along with the rapid development of internet technology today, the company's financial reporting activities can be done via the Internet in real time in an easy way and a wider scope. Internet-based financial reporting is commonly known as the Internet Financial Reporting (IFR). This research is a descriptive study that aims to determine the implementation of IFR on Islamic Banks in Indonesia. The variables in this study consisted of content, presentation and timeliness variable with a total of 112 items tested indicators. The results of this study indicate that the eleventh BUS sampled research has been able to apply IFR. IFR score obtained by each BUS has a nearly equal value ranging from $49 \%$ to $63 \%$ with the total maximum score of $100 \%$ and average score of $55 \%$.
\end{abstract}

Keywords:Internet Financial Reporting (IFR), disclosure, Islamic Banks

\section{PENDAHULUAN}

Pada era modern seperti sekarang ini, banyak hal yang dapat dilakukan dengan mudah untuk memenuhi kebutuhan setiap individu. Hal tersebut seiring dengan meningkatnya perkembangan teknologi dunia yang menyediakan berbagai fitur menarik di dalamnya. Fitur internet merupakan salah satu yang sering digunakan dalam kegiatan masyarakat sehari-hari sehingga kehadirannya pun telah menjadi sahabat bagi masyarakat.

Berdasarkan data yang diperoleh dari Internet World Stats(2015), Asia menempati urutan teratas dalam penggunaan internet di dunia. Dalam hal ini, Asia mengambil porsi yang cukup besar dengan nilai persentase sebesar 48.2\% dengan perbedaan yang cukup jauh dengan posisi kedua yang ditempati oleh Eropa dengan persentase sebesar 18\%. Di Indonesia, jumlah pengguna internet per 15 November 2015 adalah sebesar 78 juta jiwa atau setara dengan 4,8\% dari total pengguna internet di kawasan Asia.

Keberadaan internet pada era globalisasi saat ini sangatlah bermanfaat bagi berbagai kalangan masyarakat. MenurutAshbaugh et al. (1999) dan Debreceny et al. (2002) dalam Narsa \& Pratiwi (2014), internet dapat dijadikan sebagai media penyampaian informasi yang penting karena memiliki berbagai keunggulan seperti mudah menyebar (pervasiveness), tidak mengenal batas (borderless-ness), real-time, berbiaya rendah (low cost), dan mempunyai interaksi yang tinggi (high interaction) serta diintegrasi dengan teks, angka, gambar, animasi, video, dan suara. Bagi pihak perusahaan, hal ini dapat dijadikan sebagai keuntungan tersendiri, karena 
internet dapat dimanfaatkan sebagai media dalam menyediakan informasi kepada stakeholder mengenai gambaran kondisi perusahaan, informasi keuangan dan lain sebagainya melalui website perusahaan. Dengan begitu, pihak-pihak yang berkepentingan dapat mengaksesnya secara global dan real-timedimanapun mereka berada tanpa harus menunggu atau menghubungi pihak perusahaan.

Pengungkapan informasi keuangan melalui websiteini biasa disebut dengan istilah Internet Financial Reporting (IFR). IFR merupakan salah satu contoh pengungkapan sukarela (voluntary disclosure), hal ini bukan dikarenakan oleh konten pengungkapannya, akan tetapi lebih kepada alat yang digunakan (Purba, Medyawati, Silfianti, \& Hermana, 2013). Menurut Mooduto(2013), IFR adalah suatu mekanisme pengungkapan laporan keuangan perusahaan melalui internet atau melalui situs web yang dimiliki oleh perusahaan. Perusahaan yang diklasifikasikan melaksanakan IFR adalah perusahaan yang melaporkan informasi keuangan, laporan keuangan interim, dan/atau laporan tahunan lengkap melalui website perusahaan(Khan \& Ismail, 2011).

Pengungkapan informasi keuangan melalui website perusahaan dapat mengurangi terjadinya ketimpangan informasi antara pihak perusahaan dengan para investor maupun kreditur. Selain itu, dengan dilakukannya IFR maka pihak perusahaan dapat memenuhi tanggung jawabnya kepada masyarakat umum. Hal ini sesuai dengan teori stakeholder yang mengasumsikan bahwa perusahaan memiliki lingkup tanggung jawab yang luas. Perusahaan harus membuat berbagai keputusan dengan mempertimbangkan kepentingan semua pihak dalam perusahaan (tidak hanya penuntut keuangan, tetapi juga karyawan, pelanggan, masyarakat dan pejabat pemerintah) (Jensen, 2001). Hal ini dikarenakan kegiatan dan keputusan yang dibuat oleh perusahaan akan berpengaruh terhadap kesejahteraan masyarakat luas.

Melalui website perusahaan, maka pihak manapun akan dapat mengetahui dengan mudah mengenai informasi yang tercantum di dalamnya. Para investor dan krediturdapat terbantu dalam membuat keputusan investasi dan keputusan bisnis lainnya dengan sistem pelaporan yang fleksibel dan memungkinkan mereka memperoleh informasi dengan cara yang lebih mudah, cepat dan berbiaya rendah. Hal ini dikarenakan internet menyediakan bentuk unik dari pengungkapan sukarela yang memungkinkan perusahaan memberikan informasi secara global sesegera mungkin (Abdelsalam, 2007) dalam (Khan \& Ismail, 2012).

Dengan dilakukannya IFR di suatu entitas usaha yakni pencantuman informasi keuangan perusahaan melalui internet pada website resmi perusahaan, maka hal ini mendukung internet menjadi sarana utama pelaporan keuangan serta perpindahan periode paper-based reporting system menjadipaper-less reporting system(Hanifa \& Rashid, 2005). Perubahan tersebut juga merupakan suatu langkah baik karena dapat memudahkan penggunanya serta dapat meminimalisir biaya yang dikeluarkan. 
Penerapan IFR juga telah menarik perhatian dari Otoritas Jasa Keuangan (OJK) sebagai institusi yang berwenang dalam mengatur dan mengawasi jalannya sektor jasa keuangan pada perbankan, pasar modal dan Industri Keuangan Non Bank (IKNB) di Indonesia. OJK dalam "Roadmap Tata Kelola Perusahaan Indonesia (2014)" telah merekomendasikan untuk mewajibkan perusahaan publik dalam mengungkapkan informasi material tertentu melalui situs web perusahaan, karena Pedoman Umum Good Corporate Governace (GCG) di Indonesia saat ini belum mewajibkan atau mendorong perusahaan untuk mengungkapkannya. Namun demikian, BAPEPAM-LK selaku pengatur pasar modal sebelumnya telah mewajibkan Emiten atau Perusahaan Publik untuk memiliki situs web dan menyediakan beberapa informasi secara terbatas. Oleh karena itu, saat ini OJK telah menyusun Rancangan Peraturan Otoritas Jasa Keuangan tentang Situs Web Emiten atau Perusahaan Publik yang dengan begitu menandakan adanya keseriusan OJK dalam mengatur penerapan IFR di Indonesia walaupun peraturan tersebut masih berupa draft dan hanya dikhususkan kepada perusahaan publik.

Seiring dengan perkembangan teknologi seperti dalam uraian di atas, maka bank syariah pun tidak dapat mengabaikan kemajuan tersebut. Internet Financial Reporting (IFR)yang merupakan salah satu contoh perkembangan teknologi sebagai media penyampaian informasi seharusnya juga dapat dimanfaatkan secara optimal oleh industri perbankan mengingat banyaknya manfaat yang ditawarkan dari penerapan IFR itu sendiri. Terlebih lagi dikarenakan peran perbankan yang sangat penting bagi masyarakat. Sebagai media intermediasi dalam menghimpun dan menyalurkan dana masyarakat, maka terdapat kewajiban bagi pihak bank untuk dapat melakukan transparansi mengenai perkembangan usahanya kepada masyarakat luas. Hal ini berlaku pula bagi industri perbankan syariah. Kewajiban mengenai transparansi tersebut terkandung dalamPeraturan Bank Indonesia Nomor 11/33/PBI/2009 tentang Pelaksanaan Good Corporate Governance bagi Bank Umum Syariah dan Unit Usaha Syariah yang menyatakan bahwa perbankan syariah wajib melaksanakan transparansi kondisi keuangan dan nonkeuangan kepada stakeholders sebagai upaya pemenuhan salah satu prinsip Good Corporate Governance itu sendiri yaitu transparansi atau keterbukaan.

Selain memandang Peraturan Bank Indonesia (PBI) di atas, industri perbankan syariah sendiri bahkan memiliki tanggung jawab lebih dalam melakukan prinsip transparansi. Sebagai lembaga keuangan syariah, maka perbankan syariah juga dituntut untuk memenuhi kepatuhan syariah dalam menjalankan aktifitas operasionalnya. Hal ini terkandung dalam Pasal 2Peraturan Bank Indonesia Nomor 10/16/PBI/2008 tentang Perubahan atas Peraturan Bank Indonesia Nomor 9/19/PBI/2007 tentang Pelaksanaan Prinsip Syariah dalam Kegiatan Penghimpunan Dana dan Penyaluran Dana serta Pelayanan Jasa Bank Syariah. Dengan demikian, maka akan lebih banyak lagi pokok-pokok nilai yang harus diungkapkan dalam melakukan transparansi tersebut. Selanjutnya, apabila tingkatatau derajat transparansi ini mencapai tingkatyang tinggi, maka stakeholder terutamainvestor akan 
mendapat informasi yanglebih relevan, tepat waktu, bahkan lebihawal mengenai perusahaan. Jika demikian, maka hal tersebut dapat mempengaruhi keputusan investor mengenai prospek perusahaan di masa mendatang (Narsa \& Pratiwi, 2014).

Dengan diterapkannya IFR ini pada suatu entitas perusahaan seperti perbankan syariah, maka hal tersebut juga dapat memberikan keuntungan lain bagi pihak perusahaan itu sendiri yakni dalam kaitannya dengan signaling theory(teori sinyal). Menurut Wolk (2001) dalam Narsa \& Pratiwi(2014), teori sinyal merupakan teori yang menjelaskan bahwa perusahaan harus memanfaatkan informasi laporan keuangan untuk memberi sinyal positif maupun negatif kepada pihak eksternal. Dorongan untuk mengungkap informasi ini muncul sebagai salah satu cara untuk mengatasi asimetri informasi antara pihak internal perusahaan dengan pihak eksternal karena perusahaan memiliki informasi lebih banyak mengenai apa yang sudah dilakukan perusahaan dan prospek perusahaan daripada pihak eksternal.Hal ini tentu saja menjadi hal yang positif bagi perusahaan terlebih bagi perbankan syariah yang telah melakukan Initial Public Offering(IPO), karena investor akan selalu membutuhkan informasi yang simetris dalam membuat keputusan investasi. Selain itu, harga saham perusahaan yang melaksanakan IFR akan bergerak lebih cepat dibandingkan perusahaan non-IFR. Semakin tinggi tranparansi informasi yang dilakukan, maka dapat menghasilkan abnormal return yang lebih tinggi pula pada harga saham perusahaan (Lai, Lin, Li, \& Wu, 2010).

Selain sebagai industri syariah yang paling populer di masyarakat, perbankan syariah juga merupakan sektor yang paling besar kontribusinya dalam mengembangkan ekonomi syariah di Indonesia. Hal tersebut dapat dilihat dari total aset perbankan syariah dalam Statistik Perbankan Syariah per Juni 2015 yakni sebesar Rp 272.38 triliun yang jauh lebih besar dibandingkan industri syariah lainnya seperti asuransi dan pembiayaan syariah yang hanya berkisar Rp 20 triliun. Oleh karena itu, bank syariah tidak boleh terlepas dari perkembangan teknologi yang ada.Karena dengan diterapkannya IFR secara optimal, maka diharapkan dapat membantu sektor perbankan syariah dalam mengembangkan diri untuk terus meningkatkan market share-nya.

Walaupun praktik IFR menawarkan banyak manfaat yang dapat diperoleh perusahaan apabila menerapkannya dan telah berkembang pesat pada saat ini, masih banyak perusahaan yang tidak menerapkannya (Purba, Medyawati, Silfianti, \& Hermana, 2013).Masalah lainnya juga terdapat pada entitas yang sudah melaksanakan IFR. Hal ini sejalan dengan hasil penelitian Almilia (2009) mengenai komparasi indeks IFR pada website perusahaan terbuka di Indonesia yang menunjukkan bahwa perusahaan-perusahaan belum memanfaatkan secara optimal sarana yang disediakan dalam website, meskipun perusahaan-perusahaan tersebut termasuk industri perbankan yang merupakan industri dengan regulasi yang ketat. Temuan lain dalam penelitian tersebut juga menyatakan banyak perusahaan yang tidak dapat memberikan informasi yang bermanfaat bagi investor, karena kebanyakan informasi yang 
disajikan dalam website perusahaan adalah tentang produk atau jasa yang dihasilkan serta banyak sekali perusahaan yang tidak meng-update informasiinformasi yang disajikan.

Penelitian lainnya juga dilakukan oleh Khan \& Ismail (2011) dalam mengukur tingkat IFR perusahaan yang terdaftar di Bursa Malaysia. Hasil penelitian tersebut menunjukkan bahwa tingkat IFR emiten Bursa Malaysia berkisar dari 48,27\% hingga 78,16\%. Selain itu, Elhelaly \& Mohamed (2014) turut melakukan penelitian mengenai penerapan IFR pada perusahaanperusahaan di Mesir. Hasil penelitian menyatakan dari 100 perusahaan yang terdaftar diindeks EGX100 di Bursa Efek Mesir yang dianalisis, hanya 36 perusahaan yang menggunakan website dan hanya 29 perusahaan memberikan informasi keuangan di situs web mereka. Penelitian ini mengungkapkan terbatasnya penggunaan internet untuk tujuan pelaporan keuangan di Mesir. Tampak bahwa meskipun penggunaan internet sebagai media untuk penyebaran informasi perusahaan di berbagai wilayah dan Negara di dunia telah meningkat, masih banyak perusahaan yang tidak memiliki website perusahaan atau tidak menggunakan situs web merekauntuk menyebarkan informasi keuangan tersebut.

Di Indonesia sendiri telah terdapat banyak penelitian mengenai penerapan IFR, namun sebagian besar di antaranya adalah meneliti tentang faktor-faktor yang mempengaruhi penerapan IFR tersebut pada suatu entitas perusahaan. Walaupun terdapat penelitian mengenai pengukuran skor IFR di suatu perusahaan, obyek penelitian tersebut sering kali menggunakan perusahaan publik dan hal-hal yang diukur di dalamnya adalah berupa konten umum pengungkapan informasi keuangan. Dalam penelitan ini akan dilakukan analisis untuk mengukur penerapan IFR pada BUS di Indonesia dengan menyertakan pengukuran pengamatan mengenai nilai-nilai syariah di dalamnya.

Penelitian mengenai penerapan IFR pada perbankan syariah sebenarnya telah dilakukan oleh Lestari(2014). Lestari melakukan analisis jumlah pengungkapan sukarela laporan keuangan tahunan perbankan syariah melalui websitedengan hasil skor IFR bank syariah paling banyak jumlahnya pada skor $40 \%-49 \%$ dan yang tertinggi pada skor 50\%-59\% dari total skor keseluruhan skor $100 \%$. Dengan hasil tersebut dapat dikatakan bahwa sampai saat ini bank syariah belum memaksimalkan penggunaan IFR dalam mengungkapkan informasi keuangan kepada para stakeholder.

\section{TELAAH TEORITIS}

\subsection{TEORI SINYAL (SIGNALING THEORY)}

Dalam Shehata (2014) disebutkan bahwa meskipun teori sinyal pada awalnya dikembangkan untuk mengklarifikasi asimetri informasi di pasar tenaga kerja (Spence, 1973), namun teori ini telah digunakan untuk menjelaskan pengungkapan sukarela dalam pelaporan perusahaan (Ross, 1977). Jogiyanto (2000) dalam Widaryanti (2011) mengemukakan bahwa teori sinyal 
(signalling theory) membahas bagaimana seharusnya sinyal-sinyal keberhasilan atau kegagalan manajemen (agent) disampaikan kepada pemilik modal (principles). Wolk et al. (2000) dalam Sari \& Zuhrotun (2006) mengungkapkan bahwa sinyal yang diungkapkan perusahaan nantinya akan mempengaruhi investor dalam mengambil keputusan. Informasi keuangan yang positif dan dapat dipercaya akan mengurangi ketidakpastian mengenai prospek perusahaan di masa yang akan datang sehingga dapat meningkatkan kredibilitas dan kesuksesan perusahaan.

Signalling theory dapat digunakan untuk memprediksi kualitas pengungkapan perusahaan, yaitu dengan penggunaan internet sebagai media pengungkapan perusahaan dapat meningkatkan kualitas pengungkapan (Almilia, 2008). Signaling theory digunakan sebagai dasar menguji kandungan informasi dalam peristiwa pengungkapan IFR. Signaling theory mengemukakan tentangcara perusahaan memberikan sinyal kepada investor. Sinyal ini berupa informasitentang kinerja perusahaan, baik informasi keuangan maupun nonkeuangan dalam pengungkapan IFR (Mooduto, 2013).

\subsection{PENGUNGKAPAN}

Secara konseptual, pengungkapan merupakan bagian integral dari pelaporan keuangan. Sedangkan secara teknis, pengungkapan merupakan langkah akhir dari suatu proses akuntansi yaitu penyajian informasi dalam bentuk seperangkat penuh statemen keuangan. Pengungkapan sering pula dimaknai sebagai penyediaan informasi lebih dari apa yang dapat disampaikan dalam bentuk statemen keuangan formal (Suwardjono, 2005). Menurut Hendriksen (2002) dalam Hardiningsih (2008) terdapat tiga konsep pengungkapan yang umum diusulkan,yaitu:

1. Adequate disclosure (pengungkapan cukup), yaitu konsep yang sering digunakanadalah pengungkapan yang cukup, yaitu pengungkapan minimum yang disyaratkan oleh peraturan yang berlaku, dimana angkaangka yang disajikan dapat diinterprestasikan dengan benar olehinvestor.

2. Fair disclosure (pengungkapan wajar), yaitu pengungkapan yang secara tidak langsung merupakan tujuan etisagar memberikan perlakuan yang sama kepada semua pemakai laporan dengan menyediakan informasi yang layak terhadap pembaca potensial.

3. Full disclosure (pengungkapan penuh), yaitu pengungkapan yang menyangkut kelengkapan penyajian informasi yang diungkapkan secara relevan.

\subsection{INTERNET FINANCIAL REPORTING (IFR)}

Keberadaan internet telah mengakibatkan evolusi pelaporan keuangan dari desain konvensional dalam bentuk laporan tahunan cetak menjadi pelaporan keuangan kontemporer berbasis internet (Lipunga, 2014). Pelaporan berbasis internet ini biasa disebut dengan istilah Internet Financial Reporting (IFR) atau Corporate Internet Reporting(CIR). Menurut Mooduto (2013), Internet Financial Reporting(IFR) adalah suatu mekanisme pengungkapan laporan 
keuangan perusahaan melalui internet atau melalui situs web yang dimiliki oleh perusahaan.

Penelitian mengenai IFR mulai dilakukan pada tahun 1996 dan 1997 (Petravick \& Gillett, 1996; Louwers et al. 1996; Lymer (1997); Flynn \& Gowthorpe, 1997; Gray \& Debreceny, 1997), hanya selisih satu tahun setelah keberadaan internet mulai dijadikan sebagai media iklan oleh perusahaan (Allam \& Lymer, 2003). Untuk mengetahui diterapkan atau tidaknya IFR pada suatu perusahaan, terdapat beberapa klasifikasi yang ditentukan oleh para peneliti terdahulu. Menurut Chan \& Wickramasinghe (2006), perusahaan yang melakukan praktik IFR adalah perusahaan yang mengungkapkan satu set lengkap laporan keuangan termasuk catatan kaki dan laporan auditor, atau link menuju dokumen laporan tahunannya di suatu tempat dalam internet. Sedangkan menurut Khan \& Ismail(2011), kriteria perusahaan yang melakukan IFR adalah perusahaan yang melaporkan baik informasi keuangan, laporan keuangan semesteran dan/atau laporan tahunan komprehensif pada website perusahaan.

Dalam menerapkan IFR, setiap perusahaan biasanya memiliki alasannya tersendiri.Financial Accounting Standards Board(FASB) menyebutkan beberapa motif yang melatarbelakangi dilakukannya pelaporan keuangan melaluiwebsite pada suatu perusahaan, yaitu:

1. Mengurangi biaya dan waktu untuk mendistribusikan informasi

2. Berkomunikasi dengan pengguna informasi yang tak dikenal

3. Melengkapi praktik pengungkapan informasi yang biasa dilakukan dengan format cetak (tradisional)

4. Meningkatkan jumlah dan jenis data yang diungkapkan

5. Meningkatkan akses kepada investor potensial bagi perusahaan kecil

International Accounting Standards Committee (IASC)membagi cara penggunaan internet sebagai media penyajian laporan keuangan perusahaan menjadi tiga bagian, yaitu:

1. Perusahaan menyajikan laporan berupa duplikasi dari laporan keuangan yang dicetak dalam bentuk electronic paper (contoh: adobe $\operatorname{acrobat}(p d f))$

2. Mengubah format laporan keuangan dalam bentukHypertext Mark-Up Language(HTML)

3. Memaksimalkan penggunaan web sehingga terdapat perangkat tambahan yang dapat menyajikan informasi lebih lengkap dan kompleks dari laporan keuangan tradisional.

IFR sebagai salah satu media pengungkapan turut menawarkan berbagai keuntungan baik bagi pihak internal perusahaan selaku penyedia maupun pihak pengguna seperti investor, pelanggan, dll. Keuntungan tersebut di antaranya (Khanet al. 2013; Umoren \& Asogwa, 2013; Ojah \& Mokoaleli-Mokoteli, 2012; Pervan, 2006): 
1. Mempromosikan perusahaan kepada masyarakat umum sehingga mampu menarik investor lokal maupun asing.

2. Menyediakan cakupan/lingkup yang lebih luas dibandingkan dengan bentuk tradisional laporan keuangan serta memungkinkan tersedianya format laporan yang cocok untuk perhitungan.

3. Meningkatkan efisiensi dan ketepatan waktu dalam memperoleh informasi keuangan untuk membantu pengguna dalam proses pengambilan keputusan.

4. Meningkatkan transparansi pelaporan keuangan perusahaan.

5. Menyediakan informasi perusahaan secara real time dan dapat diperbarui secara terus menerus dengan biaya yang relatif lebih rendah daripada laporan berbasis kertas.

6. Menyediakan perangkat seperti hyperlink, mesin pencari, multimedia dan keterkaitan (interlinkage) antar dokumen untuk mendukung tampilan pengungkapan.

7. Memungkinkan untuk mencari, menyaring, mengunduh, mendapatkan kembali dan bahkan mengkonfigurasi ulang informasi tersebut dengan biaya rendah dalam waktu singkat.

\section{METODE PENELITIAN}

Metode yang digunakan dalam penelitian ini adalah metode penelitian kualitatif dengan pendekatan deskriptif.

Variabel yang digunakan untuk menilai pengungkapan melalui praktik IFR pada penelitian ini terdiri dari tiga bagian, yaitu variabel isi (content) dan tampilan (presentation) dan ketepatwaktuan (timeliness). Variabel ini merupakan modifikasi dan penggabungan dari beberapa variabel yang biasa digunakan untuk penelitian IFR. Untuk lebih jelasnya dapat dilihat pada tabel 2.

Tabel 1. Item Indikator Pengungkapan IFR

\begin{tabular}{|c|c|}
\hline $\begin{array}{c}\text { Variab } \\
\text { el }\end{array}$ & Item yang diungkapkan pada website BUS \\
\hline \multirow{9}{*}{ 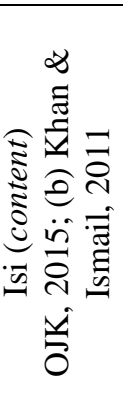 } & Laporan posisi keuangan tahun berjalan (a) \\
\hline & Laporan laba rugi komprehensif tahun berjalan (a) \\
\hline & Laporan perubahan ekuitas tahun berjalan (a) \\
\hline & Laporan arus kas tahun berjalan (a) \\
\hline & Catatan atas laporan keuangan tahun berjalan (a) \\
\hline & Laporan komitmen dan kontigensi tahun berjalan (a) \\
\hline & Perhitungan KPMM tahun berjalan (a) \\
\hline & $\begin{array}{l}\text { Jumlah \& kualitas aset produktif serta CKPN tahun berjalan } \\
\text { (a) }\end{array}$ \\
\hline & Rasio keuangan bank tahun berjalan (a) \\
\hline
\end{tabular}




\begin{tabular}{|c|c|}
\hline 10 & Transaksi spot dan transaksi derivatif tahun berjalan (a) \\
\hline 11 & Laporan distribusi bagi hasil tahun berjalan (a) \\
\hline 12 & Laporan sumber dan penyaluran dana zakat tahun berjalan (a) \\
\hline 13 & $\begin{array}{l}\text { Laporan sumber dan penggunaan dana kebajikan tahun } \\
\text { berjalan (a) }\end{array}$ \\
\hline 14 & Laporan perubahan dana investasi terikat tahun berjalan (a) \\
\hline 15 & Laporan bulanan tahun berjalan (a) \\
\hline 16 & Laporan triwulanan tahun berjalan (a) \\
\hline 17 & Laporan semesteran tahun berjalan (b) \\
\hline 18 & Laporan tahunan tahun berjalan(a) \\
\hline 19 & Laporan posisi keuangan tahun lalu (a) \\
\hline 20 & Laporan laba rugi komprehensif tahun lalu (a) \\
\hline 21 & Laporan perubahan ekuitas tahun lalu (a) \\
\hline 22 & Laporan arus kas tahun lalu (a) \\
\hline 23 & Catatan atas laporan keuangan tahun lalu (a) \\
\hline 24 & Laporan komitmen dan kontigensi tahun lalu (a) \\
\hline 25 & Perhitungan KPMM tahun lalu (a) \\
\hline 26 & Jumlah dan kualitas aset produktif serta CKPN tahun lalu (a) \\
\hline 27 & Rasio keuangan bank tahun lalu (a) \\
\hline 28 & Transaksi spot dan transaksi derivatif tahun lalu (a) \\
\hline 29 & Laporan distribusi bagi hasil tahun lalu (a) \\
\hline 30 & Laporan sumber dan penyaluran dana zakat tahun lalu (a) \\
\hline 31 & $\begin{array}{l}\text { Laporan sumber dan penggunaan dana kebajikan tahun lalu } \\
\text { (a) }\end{array}$ \\
\hline 32 & Laporan perubahan dana investasi terikat tahun lalu (a) \\
\hline 33 & Laporan bulanan tahun lalu (a) \\
\hline 34 & Laporan triwulanan tahun lalu (a) \\
\hline 35 & Laporan semesteran tahun lalu (b) \\
\hline 36 & Laporan tahunan tahun lalu(a) \\
\hline 37 & Laporan auditor tahun bejalan (b) \\
\hline 38 & Laporan auditor tahun lalu (b) \\
\hline 39 & Laporan keuangan berbahasa Inggris (b) \\
\hline 40 & Laporan setiap bagian lini bisnis tahun berjalan (b) \\
\hline 41 & Laporan setiap bagian lini bisnis tahun lalu (b) \\
\hline 42 & Laporan setiap bagian wilayah tahun berjalan (b) \\
\hline 43 & Laporan setiap bagian wilayah tahun lalu (b) \\
\hline 44 & Laporan/analisis manajemen tahun berjalan (b) \\
\hline 45 & Basis standar laporan keuangan tahun berjalan (b) \\
\hline 46 & Tambahan atau amandemen laporan tahunan berjalan (b) \\
\hline 47 & Laporan Corporate Social Responsibility (CSR) (b) \\
\hline 48 & Ringkasan laporan tahunan tahun berjalan (b) \\
\hline 49 & Halaman web berbahasa Inggris (b) \\
\hline 50 & Kebijakan akuntansi (b) \\
\hline 51 & Informasi deviden (b) \\
\hline
\end{tabular}




\begin{tabular}{|c|c|c|}
\hline & 51 & Analisis risiko utama perusahaan (b) \\
\hline & 53 & Informasi perusahaan (b) \\
\hline & 54 & Laporan direksi (b) \\
\hline & 55 & Anggota direksi (b) \\
\hline & 56 & $\begin{array}{l}\text { Ringkasan data keuangan (min. } 5 \text { thn terakhir/menyesuaikan } \\
\text { thn berdiri) (b) }\end{array}$ \\
\hline & 57 & 10 pemegang saham tertinggi tahun berjalan (b) \\
\hline & 58 & $\begin{array}{l}\text { Ringkasan rasio utama (min. } 5 \text { thn terakhir/menyesuaikan thn } \\
\text { berdiri) (b) }\end{array}$ \\
\hline & 59 & Jalan singkat mencari informasi keuangan (b) \\
\hline & 60 & Tanda tangan auditor pada laporan tahun lalu (b) \\
\hline & 61 & Piagam komite audit (b) \\
\hline & 62 & Penghargaan yang diterima pada tahun berjalan (b) \\
\hline & 63 & Informasi pemegang saham (b) \\
\hline & 64 & Alamat perusahaan $(b)$ \\
\hline & 65 & Informasi strategi perusahaan (b) \\
\hline & 66 & $\begin{array}{l}\text { Informasi tahun berjalan dapat dibedakan dengan tahun lalu } \\
\text { (b) }\end{array}$ \\
\hline & 67 & Informasi kepemilikan saham direksi (b) \\
\hline & 68 & Disclaimer/sangkalan (b) \\
\hline & 69 & Tanda tangan CEO dalam laporan (b) \\
\hline & 70 & Penjualan produk utama (b) \\
\hline & 71 & Informasi rapat umum tahunan (b) \\
\hline & 72 & Informasi rencana reinvestasi deviden (b) \\
\hline & 73 & Kode etik dan etika bagi direksi, petugas dan karyawan (b) \\
\hline & 74 & Indikator untuk menemukan informasi terkini secara cepat (b) \\
\hline & 75 & Informasi manager (min. identitas dan $C V$ eksekutif) (b) \\
\hline & 76 & Informasi proyeksi (b) \\
\hline & 77 & Informasi modal intelektual (b) \\
\hline & 78 & $\begin{array}{l}\text { Resolusi Rapat Umum Pemegang Saham (RUPS) tahun } \\
\text { berjalan (b) }\end{array}$ \\
\hline & 79 & Riwayat harga saham (b) \\
\hline & 80 & Siaran pers/berita terkini (b) \\
\hline & 81 & Prinsip/pedoman perusahaan (b) \\
\hline & 1 & Waktu memuat website dibawah 10 detik \\
\hline & 2 & Laporan tahunan dalam format pdf \\
\hline $\bar{\Xi}$ & 3 & Hyperlink analis keuangan \\
\hline క్ & 4 & Hyperlink dalam laporan tahunan \\
\hline ల్ : & 5 & Link menuju homepage \\
\hline$E_{0}^{2}$ & 6 & Link menuju top homepage \\
\hline$\Xi \varnothing$ & 7 & Kemampuan mengunduh laporan \\
\hline 츨 & 8 & Link menuju situs peta/sitemap \\
\hline $\bar{\Xi} \bar{\Xi}$ & 9 & Kontak email langsung (umpan balik) yang tersedia \\
\hline & 10 & Data keuangan dalam format processable (contoh: excel) \\
\hline & 11 & Penggunaan teknologi multimedia \\
\hline
\end{tabular}




\begin{tabular}{|c|c|c|}
\hline & 12 & Situs peta/sitemap \\
\hline & 13 & Teks hyperlink \\
\hline & 14 & Hyperlink data pada sebuah situs web pihak ketiga \\
\hline & 15 & Memungkinkan mengubah format \\
\hline & 16 & Format laporan dapat digunakan untuk perhitungan \\
\hline & 17 & Mesin pencari (search engine) internal \\
\hline & 18 & Batasan jelas untuk laporan tahunan \\
\hline & 19 & Laporan tahunan dalam format html \\
\hline & 20 & Menu pull-down \\
\hline \multirow{11}{*}{ 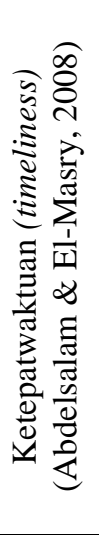 } & 1 & Tanggal terakhir pembaharuan website \\
\hline & 2 & Tahun terakhir pembaharuan website \\
\hline & 3 & Harga saham terbaru (saat ini) \\
\hline & 4 & Waktu pembaharuan khusus untuk data harga saham \\
\hline & 5 & Frekuensi pembaharuan laporan keuangan \\
\hline & 6 & Kalender kegiatan keuangan pada masa depan \\
\hline & 7 & $\begin{array}{l}\text { Opsi pendaftaran email untuk pemberitahuan berita/siaran } \\
\text { terkini, dll }\end{array}$ \\
\hline & 8 & $\begin{array}{l}\text { Informasi mengenai waktu untuk mendapat respon pertanyaan } \\
\text { melalui email dan pertanyaan online }\end{array}$ \\
\hline & 9 & Webcast(siaran melalui website) \\
\hline & 10 & Salinan berita peraturan terbaru \\
\hline & 11 & Laporan keuangan interim terbaru \\
\hline
\end{tabular}

Sumber: (Khan \& Ismail, 2011; Otoritas Jasa Keuangan, 2015; Abdelsalam \& El-Masry, 2008)

Yang menjadi populasi pada penelitian ini adalah seluruh Bank Umum Syariah (BUS) di Indonesia yang tercatat dalam Statistik Perbankan Syariah (SPS) yang dikeluarkan oleh Otoritas Jasa Keuangan (OJK) per Juni 2015 dengan jumlah 12 BUS. Sedangkan teknik pemilihan sampel yang digunakan adalah dengan metode purposive sampling dimana peneliti memberikan kriteria dalam penentuan sampel yang akan digunakan, yaitu:

1. Bank Umum Syariah yang memiliki website resmi yang aktif/dapat diakses dan tidak sedang dalam perbaikan.

2. Bank Umum Syariah yang melaksanakan IFR melalui website resminya. Bank yang dianggap melaksanakan IFR adalah perusahaan yang melaporkan informasi keuangan, laporan keuangan interim, dan/atau laporan tahunan melalui website perusahaan(Khan \& Ismail, 2011).

3. Bank Umum Syariah yang telah berdiri lebih dari dua tahun.

Data yang digunakan dalam penelitian ini adalah data sekunder berupa keterangan/informasi keuangan dan nonkeuangan yang bersumber dari website resmi masing-masing BUS. Alamat website masing-masing BUS diambil dari statistik data alamat BUS oleh OJK dan melalui bantuan search engine.

Teknik analisis data pada penelitian ini dilakukan dengan cara scoring. Pada teknik scoring ini tidak dibedakan bobot untuk setiap item 
pengungkapan. Tahapan-tahapan dalam menganalisis data pada penelitian ini yaitu:

1. Memberikan skor untuk setiap itemvariabel yang diungkapkan melalui websitebank, jika suatu item diungkapkan, maka akan diberikan skor satu (1) dan jika tidak diungkapkan akan diberikan skor nol (0).

2. Skor yang diperoleh bank pada ketiga variabel dijumlahkan untuk mendapatkan total skor pengungkapan masing-masing bank.

3. Menghitung skor kelengkapan pengungkapan (IFR Indeks) dengan menggunakan metode perhitungan yang digunakan oleh Khan \& Ismail (2011) yang cara perhitungannya sama seperti indeks pengungkapan pada umumnya (indeks wallace), yaitu dengan cara membagi total skor yang diperoleh dengan skor maksimal yang dapat diperoleh bank apabila mengungkapkan keseluruhan item.

$$
\text { IFR Indeks }=\frac{\sum \text { skor yang diperoleh perusahaan }}{\sum \text { skor maksimal }}
$$

Skor maksimal yang akan diperoleh perusahaan merupakan total item indikator dari ketiga variabel penelitian yang berjumlah 112item. Dengan rumus perhitungan tersebut, maka semakin banyak item pengungkapan yang disajikan akan semakin tinggi pula skor IFR yang diperoleh.

4. Melakukan eksplorasi terhadap hasil penelitian sesuai dengan hasil yang dipaparkan pada penelitian terdahulu, lalu memberikan kesimpulan secara umum dari hasil penelitian.

\section{PEMBAHASAN}

Sebagai lembaga intermediasi yang menghimpun dan menyalurkan dana masyarakat, terdapat tuntutan bagi Bank Umum Syariah untuk melakukan transparansi kegiatan usahanya kepada masyarakat umum seperti yang terkandung dalam Peraturan Bank Indonesia Nomor 11/33/PBI/2009 tentang Pelaksanaan Good Corporate Governance bagi Bank Umum Syariah dan Unit Usaha Syariah. Dalam rangka melakukan transparansi tersebut, BUS dapat menyajikan informasi keuangan maupun nonkeuangan melalui berbagai media salah satunya melalui website resmi perusahaan atau biasa disebut Internet Financial Reporting (IFR). Oleh karena itu, pada penelitian ini akan dilihat bagaimana luas pengungkapan informasi keuangan maupun nonkeuangan yang dilakukan oleh Bank Umum Syariah dengan IFR.

Hasil perhitungan skor IFR keseluruhan variabel penelitian dari 11 BUS berdasarkan pengamatan yang telah dilakukan oleh peneliti selama bulan April 2016 tersaji pada grafik 1 dan lebih rinci pada tabel 3. Dari data tersebut diketahui bahwa skor yang diraih oleh masing-masing BUS memiliki nilai yang hampir setara. Tidak terdapat selisih skor yang signifikan di antara 11 bank yang dijadikan sampel penelitian. 
Grafik 1. Skor IFR BUS Keseluruhan

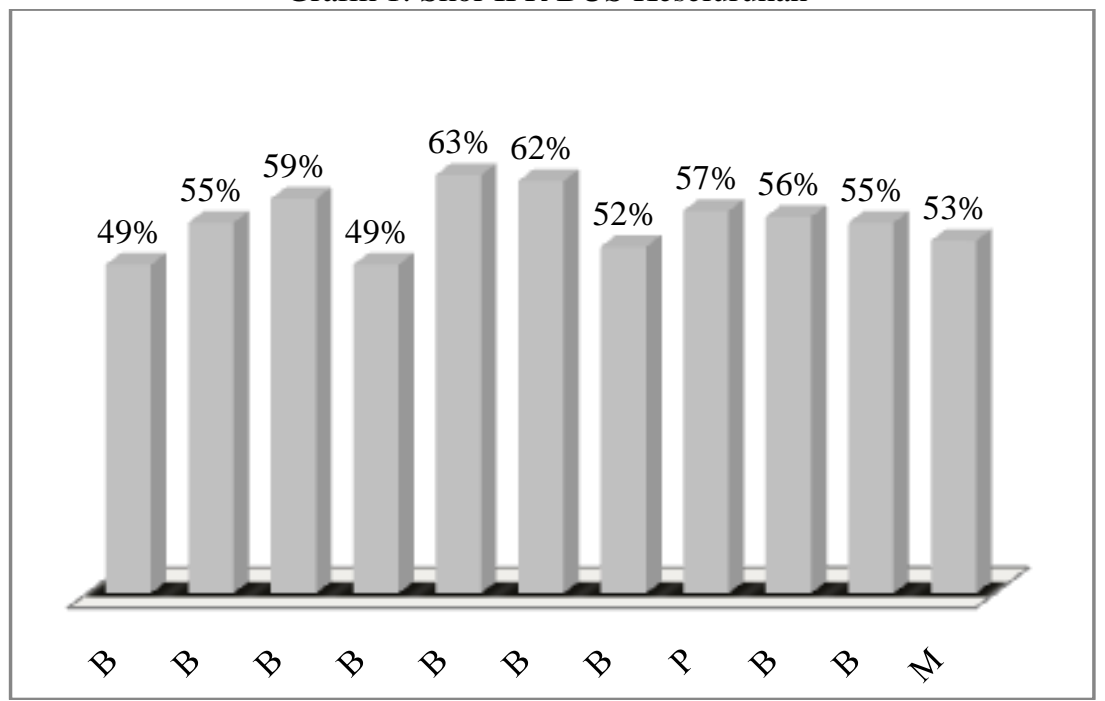

Sumber: Data diolah, 2016

Dari grafik di atas, dapat dilihat bahwa nilai tertinggi dari hasil perhitungan skor IFR diraih oleh Bank BNI Syariah (BNIS) dengan skor sebesar $63 \%$ atau dengan jumlah pengungkapan sebanyak 70item. BNIS berhasil mengungguli Bank Muamalat Indonesia (BMI) dan Bank Panin Syariah(PBS) yang saat ini statusnya telah menjadi perusahaan terbuka dan dituntut untuk lebih transparan dalam melaporkan kondisi perusahaan demi kepentingan para pemegang saham dalam mengambil keputusan investasi serta menarik perhatian calon investor. BMI bahkan menemani Bank Jabar Banten Syariah (BJBS) menjadi dua bank dengan nilai terendah pada penelitian ini, yaitu sebesar $49 \%$ atau sebanyak 53 item pengungkapan.Untuk rincian hasil perolehan skor IFR pada masing-masing BUS sendiri akan disajikan dalam tabel 3 berikut.

Tabel 2. Hasil Perolehan Skor IFR Bank Umum Syariah

\begin{tabular}{cccccccccc}
\hline \multirow{2}{*}{ No } & $\begin{array}{l}\text { Kode } \\
\text { Bank }\end{array}$ & \multicolumn{2}{c}{ Isi } & \multicolumn{2}{c}{ Tampilan } & Ketepatwaktuan & \multicolumn{2}{c}{ Skor IFR } \\
\cline { 2 - 10 } & Item & $\%$ & Item & $\%$ & Item & $\%$ & Item & $\%$ \\
\hline \multirow{2}{*}{ Total Item } & 81 & $100 \%$ & 20 & $100 \%$ & 11 & $100 \%$ & 112 & $100 \%$ \\
\hline 1 & BMI & 44 & $54 \%$ & 10 & $50 \%$ & 1 & $9 \%$ & 55 & $49 \%$ \\
\hline 2 & BVS & 49 & $60 \%$ & 11 & $55 \%$ & 2 & $18 \%$ & 62 & $55 \%$ \\
\hline 3 & BRIS & 51 & $63 \%$ & 13 & $65 \%$ & 2 & $18 \%$ & 66 & $59 \%$ \\
\hline 4 & BJBS & 43 & $53 \%$ & 10 & $50 \%$ & 2 & $18 \%$ & 55 & $49 \%$ \\
\hline 5 & BNIS & 55 & $68 \%$ & 13 & $65 \%$ & 2 & $18 \%$ & 70 & $63 \%$ \\
\hline 6 & BSM & 53 & $65 \%$ & 14 & $70 \%$ & 2 & $18 \%$ & 69 & $62 \%$ \\
\hline
\end{tabular}




\begin{tabular}{cccccccccc}
7 & BSMI & 46 & $57 \%$ & 10 & $50 \%$ & 2 & $18 \%$ & 58 & $52 \%$ \\
\hline 8 & PBS & 52 & $64 \%$ & 11 & $55 \%$ & 1 & $9 \%$ & 64 & $57 \%$ \\
\hline 9 & BSB & 49 & $60 \%$ & 12 & $60 \%$ & 2 & $18 \%$ & 63 & $56 \%$ \\
\hline 10 & BCAS & 50 & $62 \%$ & 10 & $50 \%$ & 2 & $18 \%$ & 62 & $55 \%$ \\
\hline 11 & MSI & 47 & $58 \%$ & 10 & $50 \%$ & 2 & $18 \%$ & 59 & $53 \%$ \\
\hline \multicolumn{2}{l}{ Rata-rata } & 49.00 & $60 \%$ & 11.27 & $56 \%$ & 1.82 & $17 \%$ & 62.09 & $55 \%$ \\
\hline
\end{tabular}

Sumber: Data diolah, 2016

Berdasarkan tabel di atas, diketahui bahwa hasil perolehan skor IFR BUS berada pada rentang 49\% - 63\%. Hasil ini memang belum dapat dikategorikan sebagai hal yang memuaskan atau tidak karena belum ada ketentuan mengenai hal tersebut. Namun jika dilihat dari jumlah pengungkapan BUS yang telah menyajikan sebagian besar item pengujian ditambah dengan temuan-temuan lain yang akan dibahas pada sub bab selanjutnya, dapat dikatakan bahwa informasi yang ungkapkan oleh BUS telah cukup memadai. Merujuk pada teori pengungkapan dalam prinsip dasar akuntansi, perusahaan memang dapat menyajikan kelengkapan informasi di luar pengungkapan wajib secara relevan agar mampu memberikan pengungkapan yang lebih luas mengenai kondisi yang terjadi dalam perusahaan atau yang biasa disebut dengan pengungkapan penuh (full disclosure). Namun, dalam pelaksanaannya perusahaan juga tetap harus memperhatikan batasan materialitas dan biaya seperti yang diatur dalam kerangka konseptual laporan keuangan syariah (KDPPLKS).

Disamping itu, dari tabel 3 di atas diketahui rata-rata skor IFR yang diraih oleh BUS adalah sebesar 55\% (62.09 item). Hasil ini merupakan kabar baik bagi industri perbankan syariah dimana mereka berhasil meraih skor IFR lebih dari $50 \%$ pada saat belum tersedia peraturan khusus di Indonesia mengenai tata cara penyajian informasi perusahaan melalui website. Pada saat ini, OJK sendiri masih berada pada tahap penyusunan konsep dan rancangan mengenai hal tersebut. Selain itu, rancangan peraturan tersebut belum mencakup industri perbankan syariah karena hanya ditujukan untuk mengatur situs web emiten atau perusahaan publik di Indonesia. Akan tetapi, BUS sangat terbantu dengan kehadiran Peraturan OJK Nomor 6/POJK.03/2015 tentang Transparansi dan Publikasi Laporan Bank yang telah disebutkan sebelumnya.

Seletah mengetahui hasil perhitungan skor IFR secara umum yang telah diuraikan pada pembahasan sebelumnya, maka pada bagian ini akan dijelaskan mengenai penerapan IFR pada 11 BUS berdasarkan jenis variabel penelitian yang digunakan, yaitu variabel isi, variabel tampilan dan variabel ketepatwaktuan. Hasil skor dari setiap bank tersebut kemudian akan dikelompokkan berdasarkan rentang nilainya seperti yang telah dilakukan oleh para peneliti terdahulu (Khan \& Ismail, 2011; Almilia, 2009).

Setelah mendapatkan hasil skor penilaian IFR pada seluruh BUS dan dilakukan analisis data pada masing-masing variabel penelitian. Maka 
peneliti dapat memberikan peringkat kepada 11 BUS sesuai dengan skor IFR keseluruhan yang telah diperoleh. Hasil tersebut dapat dilihat pada tabel 4.9 yang menerangkan urutan peringkat BUS dalam melaksanakan IFR mulai dari skor tertinggi hingga terendah.

Berdasarkan data pada tabel 4 tersebut, peringkat pertama skor IFR tertinggi pada BUS saat ini diraih oleh PT. Bank BNI Syariah dengan jumlah pengungkapan 70item atau dengan skor IFR sebesar 63\%. Urutan kedua dengan selisih 1 item pengungkapan ditempati oleh PT. Bank Syariah Mandiri dengan skor $62 \%$ dan diikuti oleh PT. Bank BRISyariah, PT. Bank Panin Syariah Tbk. dan PT. Bank Syariah Bukopin yang menempati urutan ke 3,4 dan 5. Sedangkan urutan terakhir diduduki bersama oleh PT. Bank Muamalat Indonesia Tbk. dan PT. Bank Jabar Banten Syariah dengan skor IFR $49 \%$.

Tabel 3. Peringkat Skor IFR BUS di Indonesia

\begin{tabular}{clll}
\hline Peringkat & Nama Bank & Skor IFR & Jml Item \\
\hline 1 & PT. Bank BNI Syariah & $63 \%$ & 70 \\
\hline 2 & PT. Bank Syariah Mandiri & $62 \%$ & 69 \\
\hline 3 & PT. Bank BRISyariah & $59 \%$ & 66 \\
\hline 4 & PT. Bank Panin Syariah Tbk. & $57 \%$ & 64 \\
\hline 5 & PT. Bank Syariah Bukopin & $56 \%$ & 63 \\
\hline \multirow{2}{*}{$\begin{array}{l}\text { PT. Bank Victoria Syariah } \\
\text { PT. Bank BCA Syariah }\end{array}$} & $55 \%$ & \multirow{2}{*}{62} \\
\hline 8 & PT. Bank Maybank Syariah Indonesia & $53 \%$ & 59 \\
\hline \multirow{2}{*}{9} & PT. Bank Mega Syariah & $52 \%$ & 58 \\
& $\begin{array}{l}\text { PT. Bank Muamalat Indonesia Tbk. } \\
\text { PT. Bank Jabar Banten Syariah }\end{array}$ & $49 \%$ & \multirow{2}{*}{55} \\
\hline
\end{tabular}

Sumber: Data diolah, 2016

Dengan adanya peringkat di atas, setiap bank dapat mengetahui bagaimana kualitas dan kuantitas kegiatan penyampaian informasi perusahaan baik keuangan dan nonkeuangan dalam website resmi yang dimilikinya atau yang biasa disebut dengan istilah Internet Financial Reporting (IFR). Dengan begitu, perusahaan dapat meningkatkan ataupun mempertahankan kualitas yang telah diraihnya.

\section{SIMPULAN}

Kesebelas BUS yang dijadikan sampel penelitian sudah dapat melaksanakan Internet Financial Reporting (IFR) dan mencapai rata-rata skor IFR keseluruhan sebesar 55\% (62,09item) dengan distribusi skor IFR masingmasing BUS yang tidak jauh berbeda, yakni berkisar mulai dari $49 \%$ hingga $63 \%$.

BUS di Indonesia pada saat ini sudah cukup luas mengungkapkan informasi yang dimilikinya. Hasil pengamatan pada variabel isi menyatakan bahwa 7 dari 11 bank sampel penelitian telah berhasil menyajikan item 
pengungkapan dengan skor $60 \%-69.9 \%$, sedangkan 4 lainnya berada pada skor $50 \%-59.9 \%$.

Sebagian besar BUS yang kurang memanfaatkan kelebihan yang disediakan oleh website dalam mendukung tampilan informasi yang disajikan, seperti penggunaan format laporan yang interaktif. Sebagian besar BUS hanya menyajikan laporan publikasinya dengan format pdf yang notabenenya akan terlihat sama seperti laporan keuangan cetak. Namun hasil skor IFR untuk variabel tampilan menunjukkan bahwa kesebelas BUS telah menggunakan lebih dari 50\% item indikator tampilan yang diujikan dengan nilai tertinggi yang mencapai $70 \%$ atau setara dengan 14 dari 20 item pengungkapan yang diujikan.

Hasil pengujian pada variabel ketepatwaktuan memberikan hasil yang kurang memuaskan, karena nilai tertinggi BUS hanya mencapai skor $18 \%$ atau sebanyak 2 dari 11 item yang diujikan. Akan tetapi, pengujian ketepatwaktuan publikasi laporan berdasarkan Peraturan OJK Nomor 6/POJK.03/2015 menunjukkan hasil yang baik, karena banyak BUS yang telah mempublikasikan laporannya secara tepat waktu berdasarkan ketentuan pada peraturan tersebut.

\section{DAFTAR PUSTAKA}

Abdelsalam, O., \& El-Masry, A. (2008). The impact of board independence and ownership structure on the timeliness of corporate internet reporting of Irish-listed companies. Managerial Finance, 34(12), 907918.

Agboola, A. A., \& Salawu, M. K. (2012). The Determinants of Internet Financial Reporting: Empirical Evidence from Nigeria. The International Institute for Science, Technology and Education (IISTE), 3 (11)

Allam, A., \& Lymer, A. (2003). Developements in Internet Financial Reporting: Review and Analysis Across Five Developed Countries. The International Journal of Digital Accounting Research, 3 (6), 165199.

Almilia, L. S. (2008). Faktor-faktor yang Mempengaruhi Pengungkapan Sukarela "Internet Financial and Sustainability Reporting". Jurnal Akuntansi dan Auditing Indonesia, 12 (12), 117-131.

Almilia, L. S. (2009). Analisa Komparasi Indeks Internet Financial Reporting Pada Website Perusahaan Go Publik Di Indonesia. In Seminar Nasional Aplikasi Teknologi Informasi (SNATI)., ISSN: 1907-5022, 31-32.

Aly, D., Simon, J., \& Hussainey, K. (2010). Determinants of Corporate Internet Reporting: Evidence from Egypt. Managerial Auditing Journal, 25 (2), 182-202. 
Bank Indonesia. (2007). Peraturan Bank Indonesia Nomor 9/19/PBI/2007 tentang Pelaksanaan Prinsip Syariah dalam Kegiatan Penghimpunan Dana dan Penyaluran Dana serta Pelayanan Jasa Bank Syariah. Jakarta: BI.

Bank Indonesia. (2008). Peraturan Bank Indonesia Nomor 10/16/PBI/2008 tentang Perubahan atas Peraturan Bank Indonesia Nomor 9/19/PBI/2007 tentang Pelaksanaan Prinsip Syariah dalam Kegiatan Penghimpunan Dana dan Penyaluran Dana serta Pelayanan Jasa Bank Syariah. Jakarta: BI.

Bank Indonesia. (2009). Peraturan Bank Indonesia Nomor 11/33/PBI/2009 tentang Pelaksanaan Good Corporate Governance bagi Bank Umum Syariah dan Unit Usaha Syariah. Jakarta: BI.

Chan, W. K., \& Wickramasinghe, N. (2006). Using the internet for financial disclosures: the Australian experience. International Journal of Electronic Finance, 1(1), 118-150.

Elhelaly, M., \& Mohamed, E. K. (2014). A Survey of Internet Financial Reporting in Egypt. International Journal of Accounting and Financial Reporting, 4(1), 70.

FASB. (2000). Business Reporting Research Project: Electronic Distribution of Business Reporting Information. Steering Committe Report Series, 1 .

Haniffa, M. H., \& Rashid, H. M. A. (2005). The Determinants of Voluntary Disclosures in Malaysia: The Case of Internet Financial Reporting. UNITAR e-Journal, 2(1), 22-42.

Hardiningsih, P. (2008). Analisis faktor-faktor yang mempengaruhi voluntary disclosure laporan tahunan perusahaan. Jurnal Bisnis dan Ekonomi, 15(1), 67-79.

IASC. (1999). Business Reporting on the Internet. International Accounting Standards Committee, 48.

Jensen, M. (2001). Value maximisation, stakeholder theory, and the corporate objective function. European financial management, 7(3), 297-317.

Khan, M. N. A. A., \& Ismail, N. A. (2011). The level of internet financial reporting of Malaysian companies. Asian Journal of Accounting and Governance, 2, 27-39.

Khan, D. M., \& Ismail, P. D. (2011). The Use of Disclosure Indices in Internet Financial Reporting Research. Journal of Global Business and Economics, 3 (1).

Khan, M. N. A. A., \& Ismail, N. A. (2012). Users' Perceptions of Various Aspects of Malaysian Internet Financial Reporting. Journal of Organizational Management Studies, 2012, 1. 
Lai, S.-C., Lin, C., Li, H.-C., \& Wu, F. H. (2010). An Empirical Study of the Impact of Internet Financial Reporting on Stock Prices. The International Journal of Digital Accounting Research, 10, 1-26.

Lestari, N. (2014). Analisis Jumlah Pengungkapan Sukarela Laporan Keuangan Tahunan Perbankan Syariah melalui Website. Skripsi Mahasiswa Universitas Islam Negeri Sunan Kalijaga Yogyakarta.

Lipunga, A. M. (2014). Internet Financial Reporting in Malawi. International Journal of Business and Management, 9 (6).

Mooduto, W. I. S. (2013). Reaksi Investor atas Pengungkapan Internet Financial Reporting. Jurnal Reviu Akuntansi dan Keuangan, 3(2), 479-492.

Narsa, I. M., \& Pratiwi, F. F. (2017). Internet financial reporting, pengungkapan informasi website, luas lingkup pelaporan internet, dan nilai perusahaan. EKUITAS (Jurnal Ekonomi dan Keuangan), 18(2), 259-273.

Ojah, K., \& Mokoaleli-Mokoteli, T. (2012). Internet financial reporting, infrastructures and corporate governance: An international analysis. Review of Development Finance, 2(2), 69-83.

Otoritas Jasa Keuangan. (2014). Roadmap Tata Kelola Perusahaan Indonesia .p. 41.

Otoritas Jasa Keuangan. (2015). Peraturan Otoritas Jasa Keuangan Nomor 6/POJK.03/2015 tentang Transparansi dan Publikasi Laporan Bank.

Otoritas Jasa Keuangan. (2015). Salinan Surat Edaran Otoritas Jasa Keuangan Nomor 18/SEOJK.03/2015 tentang Transparansi dan Publikasi Laporan Bank Umum Syariah dan Unit Usaha Syariah.

Otoritas Jasa Keuangan. (Juni 2015). Statistik Perbankan Syariah.

Pertiwi, A. D., \& Hermana, B. (2015). Comparing Internet Financial Reporting Index Between Bank and Non Bank in Indonesia. The Journal of Internet Banking and Commerce, 18 (2).

Pervan, I. (2006). Voluntary financial reporting on the internet: analysis of the practice of stock-market listed croatian and slovene joint stock companies. Financial theory and practice, 30(1), 1-27.

Purba, L., Medyawati, H., Silfianti, W., \& Hermana, B. Internet Financial Reporting Index Analysis: An Overview from the State Owned Enterprises in Indonesia. Journal of Economics, Business and Management, 1 (3).

Sari, R. C., \& Zuhrotun. (2006). Keinformatifan Laba di Pasar Obligasi dan Saham: Uji Liquidation Option Hypothesis. Simposium Nasional Akuntansi 9 Padang, K-AKPM 08. 
Shehata, N. F. (2014). Theories and Determinants of Voluntary Disclosure. Accounting and Finance Research, 3 (1).

Suripto, B. (2006). Praktik Pelaporan Keuangan dalam Website Perusahaan Indonesia. Jurnal Akuntansi dan Manajemen, XVII (1), 41-56.

Suwardjono. (2005). Teori Akuntansi: Perekayasaan Pelaporan Keuangan, Edisi Ketiga. Yogyakarta: Fakultas Ekonomi dan Bisnis UGM.

Widaryanti. (2011). Analisis Faktor-Faktor yang Mempengaruhi Ketepatan Waktu Corporate Internet Reporting pada Perusahaan-Perusahaan yang Terdaftar di Bursa Efek Indonesia. Jurnal Ilmu Manajemen dan Akuntansi Terapan, 2 (2). 
